\title{
What schools teach us about educating poor children in Chile
}

\author{
Beverley A. Carlson \\ Social Affairs Officer, \\ Division of Production, \\ Productivity and Management, \\ Economic Commission \\ for Latin America \\ and the Caribbean (ECLAC) \\ bcarlson@eclac.cl
}

\begin{abstract}
A great deal of effort has been put into education reform in Latin America since the early 1990s. Extending the coverage of educational opportunities and improving the quality of the education delivered in schools are crucial for the countries of the region, where education in State schools has often been of a low standard. It is not enough just to study macro education policies as they are formulated by governments and implemented by centralized ministries of education. What is promised or envisioned on paper is often quite different from what actually happens in school establishments. It is important to understand, at the micro level, how schools are functioning in practice as they implement educational policies. Educational policies and social reality come together in school classrooms and schools can teach us a great deal about achieving quality in basic education. The focus of this article is on poor children in poor schools and the continuing challenges of educating children in poor communities. Chile's national programme to improve the quality of education and educational outcomes in 900 of its poorer primary schools, known as the P900 programme, provided an ideal framework for identifying and studying the challenges faced by schools in poor communities in trying to deliver a high-quality education to their children and for understanding how and why they are struggling to meet national standards. This study is concerned with learning from schools to achieve a better understanding of what they see, in the context of their community and the student population they serve, as the practical realities of educating poor children. At the national level, a macro research methodology was used to identify the worst-performing schools in the P900 programme on the basis of their results in standardized examinations and the trends seen in these results over the 1990s. A small purposive sample of the worstperforming schools was drawn from this group and quota sampling techniques were used to ascertain their main characteristics. A micro study of each of the schools selected was then carried out, involving school visits and interviews to understand school and pupil performance and to identify critical factors that might be amenable to change. In-depth reports were prepared on each school. This article synthesizes the lessons learned from these micro studies.
\end{abstract}


I

\section{Evaluating education quality: macro to micro}

A great deal of effort has been put into education reform in Latin America since the early 1990s. ${ }^{1}$ In Chile, a major emphasis of reform is on improving the quality and equity of education in the public sector. ${ }^{2}$ The country is striving to improve education through initiatives in four main areas: reforming the curriculum, strengthening university teacher training programmes, extending basic education ${ }^{3}$ from half-day shifts to fullday schooling and improving quality. These initiatives began in the early 1990s but the undertaking is a considerable one and the impact of the reforms, to the extent they are successful, will necessarily take time to come through.

Educational reform and national education policies do not automatically translate into better education in schools. Reforms - to the macro, legal and financial framework- are an important starting point. Turning reforms into policies, programmes, delivery and actions affecting students in schools, though, is a great challenge involving many actors and variables. Reforms are statements of intent. Consequently, it is not enough just to evaluate stated reforms. The place to look for

This article synthesizes and amplifies the findings of a macromicro study entitled Achieving educational quality: What schools teach us published by ECLAC in January 2000. The author would like to express her gratitude to the Chilean Ministry of Education and its P900 schools programme, provincial and municipal authorities and, especially, each of the schools in the study that shared their time, energy and knowledge. These schools are the centre of this work. The author would like to thank Jorge Katz for his valuable comments on the draft version of this article, Joe Ramos for his advice on project design and comments on an earlier version, Pilar Bascuñán, Elizabeth Love and Howard La Franchi for their expertise and help with school interviews and reporting and the school principals, teachers, children and parents who gave their time and their insights into the continuing challenges of educating children in poor communities.

${ }^{1}$ See Gajardo (2000), World Bank (1999), PREAL (1998) and Rojas and Esquivel (1998).

${ }^{2}$ See García-Huidobro (1999), García-Huidobro and Jara (1994), Schiefelbein and Schiefelbein (1999), Cox (1997) and Carnoy and McEwan (1997).

${ }^{3}$ In Chile, compulsory basic (primary) education lasts for eight years. achievements is in schools and their individual student outcomes: the micro perspective.

The focus of this article is on poor children in poor schools, the continuing challenge of educating children in poor communities, and what this can teach us about achieving quality in basic education. ${ }^{4}$ Because the school is the bottom rung on a bureaucratic ladder of important education delivery actors, it is necessary first to understand the unusual structure of basic education in Chile and the reasons behind it. The Chilean education system is a mixed public-private one. There are three types of primary school: municipal schools which receive central government funding (called a subvention) and are administered by municipalities, private schools which receive the same central government subvention and are privately run, and privately financed, privately managed schools. This tripartite arrangement is the legacy of a school reform in the early 1980s that transferred school management away from central government authorities and made it a local municipal or private responsibility. It is also a result of government policy at the time, which aimed to create incentives for the private sector to provide educational facilities and introduce competition into the system. Effectively, about $8 \%$ of primary schools are fully private, i.e. in the third category. Just over a quarter of school establishments are in the mixed category of private schools that receive the central government subvention, and the remaining two thirds are municipal.

Education policies and social reality come together in the classroom in schools across the country. In evaluating educational quality, it is not sensible or fair to compare student and school performance solely on the basis of standardized test results. Students enter school with "quality" differences that result from a multiplicity of factors ranging from brain development, which is enormously affected by early childhood nutrition and care, to positive home learning environments and social interaction. These factors limit what schools alone can achieve in purely numerical terms, especially when

\footnotetext{
${ }^{4}$ See Carlson (2000).
} 
they are located in poorer socially and economically disadvantaged neighbourhoods where they face much greater challenges than do schools that are located in richer neighbourhoods.

Education quality cannot be evaluated solely on the basis of which students and schools have the highest scores in standardized exams, since different schools are teaching very different types of students. Ideally, we would like to be able to evaluate individual improvements in student performance as children progress through primary and secondary school. This is rarely possible. At best, in some countries, we have national and international educational testing, often in the fourth and eighth grades, which provides a cross-sectional evaluation of the performance of fourth and eighth graders that year. These results, when aggregated to the school level, provide a snapshot of the performance of fourth and eighth grade students in individual establishments.

This is the case in Chile with the Sistema de Medición de la Calidad de la Educación (Education Quality Measurement System), or SIMCE. The annual SIMCE school results are widely available and are even published in national newspapers. Parents and students are encouraged to consult them. These statistics can serve many purposes, and they have been well used and misused. ${ }^{5}$ Ricardo Lagos, former Minister of Education and now President of the Republic, has said that SIMCE school results are the only way of evaluating school performance objectively at a national level in order to provide special help to poorer, more needy

\footnotetext{
${ }^{5}$ Appropriate use of SIMCE results for fourth grade needs to take into account known measurement and interpretation problems which have been discussed by several researchers: see Martínez (1996), Espínola (1996), Olivares (1996) and, most notably, Rodríguez (1996). These can produce an upward bias which may artificially inflate scores, especially in schools with poor educational quality and smaller schools. Published statistics on trends in average performance by school type, e.g., municipal, private subvention or P900, are distorted by many factors including the continuity of the testing instru-
}

schools (see Undurraga, 1998). Again, schools have used good SIMCE results to market themselves in order to attract more students, especially in the case of private schools receiving public subsidies. This is important because the great bulk of school subsidies are linked to the number of pupils attending. Parents also use the annual school results, published in local newspapers, to help them select the best school for their children.

Many school administrators and teachers have a different view. They find SIMCE an unfair yardstick of their performance and the performance of their students, especially in poorer neighbourhoods. They feel that it does not take into account the differential capacities of their student populations and the differential resources available to schools, or the degree of parental interest and participation. Each of these views is meaningful.

In short, student outcome data are a very useful performance measure if employed appropriately. But they tell us only the end result, the "what". More important than the "what" is the "why". In order to understand learning outcomes it is essential to understand what happens at school. What can schools teach us? The school is the centre of learning for at least twelve years of a person's life. Yes, we know that out-of-school factors are terribly important, particularly in poor neighbourhoods and poor families. But the school is still the first level of institutional responsibility for student learning. For that reason it is essential to "get down to the school" and study the "school reality" if we are to understand the many factors that come into play there.

ments, the effects of many new schools carrying out testing (Mizala and Romaguera, 1998) and the continuing issue of how examinations are marked. Others (Eyzaguirre and Fontaine, 1999) are concerned about the low difficulty level of eighth grade SIMCE, corresponding to two to three grades below grade level, which they worry may be a limiting factor in educational quality improvements and which they observe shows a lack of continuity between the requirements of basic and secondary education. These issues are beyond the scope of this study but have been kept in mind. 


\section{II}

\section{Educational performance in poor schools}

The Chilean education authorities provided an opportunity to examine educational performance in relation to the national programme for improving the quality of educational outcomes in 900 of Chile's poorer primary schools, known as the P900 Programme. ${ }^{6}$ The education authorities were interested in finding out why some schools did not improve despite having had years of special inputs and attention from this programme, and wanted help in doing so in order to take corrective action. Initially, ECLAC had proposed just the reverse: to investigate why some schools excelled in spite of common difficulties and to disseminate "lessons learned". In any event, similar issues arise whether one is trying to measure why some schools and students excel or why some schools and students do not measure up to expectations. Both approaches need to combine an assessment of quantitative results with qualitative research that can explain these results.

It was decided to concentrate on the school as the centre of learning and decision-making and to study what happens in schools at first hand. Schools are where educational policies and programmes are implemented and put to the test within the context of the many factors that play a role in achieving educational quality. The school is the "front line" where school authorities first confront the situation of children and their preparedness for learning. It is where the intangibles become tangible. Consequently, the key feature of this study is the knowledge gained from within school establishments, since the school is where policy and practice are played out.

The research was carried out during the 1998 school year, which in Chile is March to December. We proposed a two-pronged methodology that in general terms used both quantitative and qualitative methods. It was essential that unbiased quantitative methods be used to identify the so-called "worst P900 schools" and track their performance over time on the basis of their SIMCE results since 1990, when P900 began. Over 2,100 municipal and private primary schools in receipt of the government subvention had participated in the P900

\footnotetext{
${ }^{6}$ See numerous documents on P900 and SIMCE published by the Chilean Ministry of Education. See also Angell (1996).
}

for one or more years. Out of this large number of schools, a core group of 308 schools that had participated in P900 for five years or more and had still not graduated from the programme was identified, and from those the 100 currently worst-performing schools were selected. A small purposive sample of poorly performing schools was then drawn from this last group using quota sampling techniques to reflect the main characteristics of these schools with respect to the major domains of interest, i.e. urban and rural schools, small, medium-sized and large schools, poorer and better off schools, schools in different geographical regions, and municipal and private schools receiving public support (see section III).

The study uses fourth grade SIMCE scores for 19901996 with follow-up on eighth grade SIMCE performance through to 1997. In 1996, curriculum changes began to be introduced in grades 1 to 4 , followed by curriculum changes in grades 5 to 8 in later years. The testing system was changed accordingly. Therefore, the 1990-1996 SIMCE results were the last "comparable" cohort for grades 1 to 4 (and the 1991-1997 SIMCE results were the last comparable ones for grades 5 to 8 ). The availability of comparable results over this many years made it possible to track performance and investigate reasons for changes or lack of improvement over an extended period. Average 1990-1996 SIMCE scores for fourth grade mathematics and Spanish are shown in figure 1 and illustrate the performance patterns of different school types.

The theoretical maximum score in SIMCE tests is 100. During the period under study the average performance of fourth grade students in subsidized schools, ${ }^{7}$ both municipal and private, increased by 11 SIMCE points to reach a high of 70 in 1996. There was a similar improvement of 12 SIMCE points among P900 schools. This suggests a broad-based improvement in educational performance if, in fact, the SIMCE

\footnotetext{
${ }^{7}$ Rather less than $70 \%$ of subsidized schools took the SIMCE test in 1996, partly because of exclusion and disqualification rules and partly because some schools opted not to participate. Small and remote schools were most likely not to have participated. However, to be considered for inclusion in the P900 programme schools were required to have taken SIMCE.
} 
FIGURE 1

Chile: Average scores in fourth grade SIMCE $^{a}$ mathematics and Spanish tests, 1990-1996

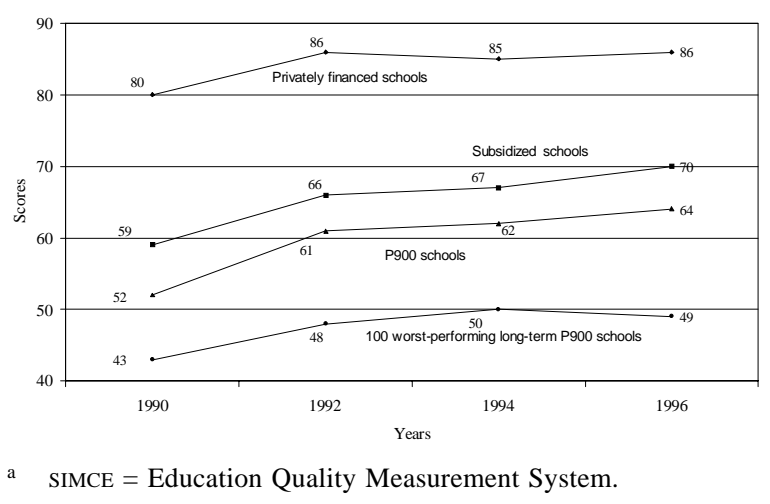

examination measurement standards were kept constant. Again, it is not possible to say how much of the increase in the P900 scores was due to improvement in individual schools and how much to the recruitment into the programme of new schools with better SIMCE performance to begin with. In both groups there was a similar large, one-off improvement in performance between 1990 and 1992, much greater than in any subsequent period.

The SIMCE performance of unsubsidized private schools shows a very large gap between the educational performance and opportunities of the elite $8 \%$ of students whose families can afford to enrol them in strictly private schools and those of children from middle class and poor families attending publicly subsidized schools. Children attending the elite schools achieved a high of 86 SIMCE points in 1996, nearly double the score of the 100 worst-performing long-term P900 schools which are the subject of this study.

Approximately 900 schools participate in P900 each year. Of the more than 2,100 school that have participated in P900 since 1990, in 1996 there were still 308 under-performing schools that had not been able to graduate out of the system even after five years or more of P900 programme support. The SIMCE scores of the 100 worst-performing schools in this group of long-term P900 schools, i.e. the bottom third, are also shown in figure 1. After an initial but relatively small rise in their scores in 1992 these schools stagnated, and between 1994 and 1996 there was actually a slight decline. It is these under-performing P900 schools that are the concern of the study.

It should be noted that these under-performing schools are not necessarily the "poorest of the poor", nor even very poor. This is illustrated by the vulnerability index of each school. Table 1 shows the vulnerability indices of the poor schools visited for the study. The Junta Nacional de Auxilio Escolar y Becas (National Student Assistance and Scholarship Board) or JUNAEB vulnerability index is used to decide the distribution of school feeding programmes, so that more food can be targeted at the neediest. The index goes from one to five, one indicating minimum vulnerability and five maximum vulnerability. The schools visited ranged in vulnerability from two to five, so they included low and medium, as well as high, vulnerability children. This is because P900 aims for some regional balance while poor schools tend to be highly concentrated in certain regions. The poorest schools are much more likely to be found among the 2,500 primary schools that were excluded or disqualified from the SIMCE tests. The great majority of them are very poor rural schools, often small, often difficult of access. When these schools receive educational assistance it is usually under the Programa de Mejoramiento de la Calidad y Equidad de la Educación (MECE), a programme designed to improve the quality and equity of education in smaller poor rural schools.

In drawing conclusions from this study it should be borne in mind that more than one third of subsidized schools are no better and probably worse off than the schools studied here. The many lessons learned from the school visits will certainly be relevant for a significant proportion of the country's subsidized primary schools, be they municipal or private, and will be very important for improving the quality and equity of primary education. 


\section{III}

\section{Micro research methodology}

This paper synthesizes the micro evidence from the school visits, and draws conclusions about the macro quality issues. Essentially, the macro-micro evidence can be distinguished as the "macro-what" and the "micro-how". At the macro level, performance indicators, statistics, policies, programmes and financing are the guiding forces. At the micro level, schools tell us "how the whats are implemented" in practice and in the context of the client group, the student population served by the schools.

The qualitative methods involved daylong visits to each of the sampled schools by a two-person team comprising the project director and an accompanying journalist. In-depth interviews were conducted with all the principal actors: students, teachers, school principals, parents, school administrators and provincial and municipal education authorities. Children in the fourth grade were the group of greatest interest. This is due to the fact that in the period of analysis the P900 programme was targeted at children in the first cycle, i.e. the first four grades. Also, it was the fourth grade that SIMCE tested every two years, thereby providing a convenient output measure of fourth grade performance and, indirectly, of P900 performance/impact at the school level.

Eighth grade school performance also proved to be useful for assessing school performance in the second cycle, grades 5 to 8 , and for measuring whether the early P900 input was having a continuing impact as students progressed through the system.

Done properly, the micro research is timeconsuming, and it has to be carefully planned so that unbiased, truthful, unrehearsed feedback can be obtained from the school. The project director should ideally visit each school to ensure consistency and to build on lessons learned in earlier interviews. These interviews should be conducted in private, without the presence of Ministry of Education or local or provincial officials, in order to give respondents the best opportunity to provide candid comments. While the interviews were scripted insofar as questions were prepared in advance of school visits and tailored to each type of interview (school principal, technical director, fourth grade teacher, all teachers, students, parents, provincial and municipal authorities), these questions were used flexibly and developed upon in view of the way the interviews were progressing. To the extent that information may differ from that available at the national level, this is due to differences of perception and knowledge among local authorities and school officials.

The schools were selected on the basis of the following criteria:

- The schools had to be currently in the P900 programme.

- They had to have been in the P900 system for five years or more and never graduated.

- Their average fourth grade mathematics and Spanish SIMCE score in 1996 (the latest year available) had to be 60 or less.

- The past trend in average fourth grade mathematics and Spanish SIMCE scores had to place them in the "hard core" of under-performing long-term P900 schools. Their scores had to show a steady or periodic deterioration or an obvious lack of improvement in contrast to the steady improvement in comparable scores shown by the P900 schools as a whole.

- Only one school could be selected in any region.

- One or two schools had to be subsidized private schools as opposed to municipal schools, to reflect the fact that about $25 \%$ of the P900 schools are subsidized private schools.

- Half the schools had to be urban and half rural, reflecting the P900 school split of $46 \%$ urban to $54 \%$ rural.

- The wide range of school enrolment sizes had to be captured.

- The full range of years spent in the P900 system by longterm schools (five to eight years) had to be covered.

- Average fourth grade mathematics and Spanish SIMCE scores vary considerably among regions. Since one of the criteria for including a school in the P900 system is the ratio between the school's SIMCE score and the average regional SIMCE score, the selected schools had to reflect this regional range of SIMCE scores.

- As many as possible of the five quintiles of the proportion of vulnerable children by commune, as assessed by the JUNAEB vulnerability index, had to be represented. 
These criteria ${ }^{8}$ were carefully classified and analysed for the nearly 900 current P900 schools, and from these the 100 schools with the lowest SIMCE results were identified and a stratified shortlist of 24 was drawn up. The principal aim was to probe as deeply as possible into each school, looking at all factors and consulting each of the actors. In order to achieve this level of understanding, and in view of presentational factors and the time and resources available, it was decided to visit just six schools, as visiting all 24 would have produced too many case studies and would not have enabled sufficient attention to be devoted to each school. Accordingly, six of the 24 shortlisted schools were selected, with quota sampling being used as opposed to random sampling techniques to reflect the main characteristics of this group of schools with respect to as many aspects of each variable as possible. It can be seen from table 1 that the $\mathrm{P} 900$ schools where the visits and interviews took place met the criteria and covered nearly all aspects of the key variables. In addition, two comparable schools that had done very well and graduated from the programme were interviewed to gain further insights.

Only once the final list of schools had been drawn up was the exact location of each identified on a map (see map 1). Thus, convenience and ease of access were not factors in choosing the schools. Reaching one school in Taltal involved a four hour bus trip each way from the nearest airport (Antofagasta) and two overnight stays in the town. Another school in Chañaral Alto was a one hour drive from Ovalle, which was itself a two hour drive away from the nearest airport (La Serena). The Popoén and Trangol school visits involved an extended period of travel lasting four days, Osorno and Temuco airports being the respective starting points. The result was eight complete, in-depth school case studies. ${ }^{9}$ A brief description of the selected schools is given in table 1.
MAP 1

Chile: Location of schools visited

for the micro studies

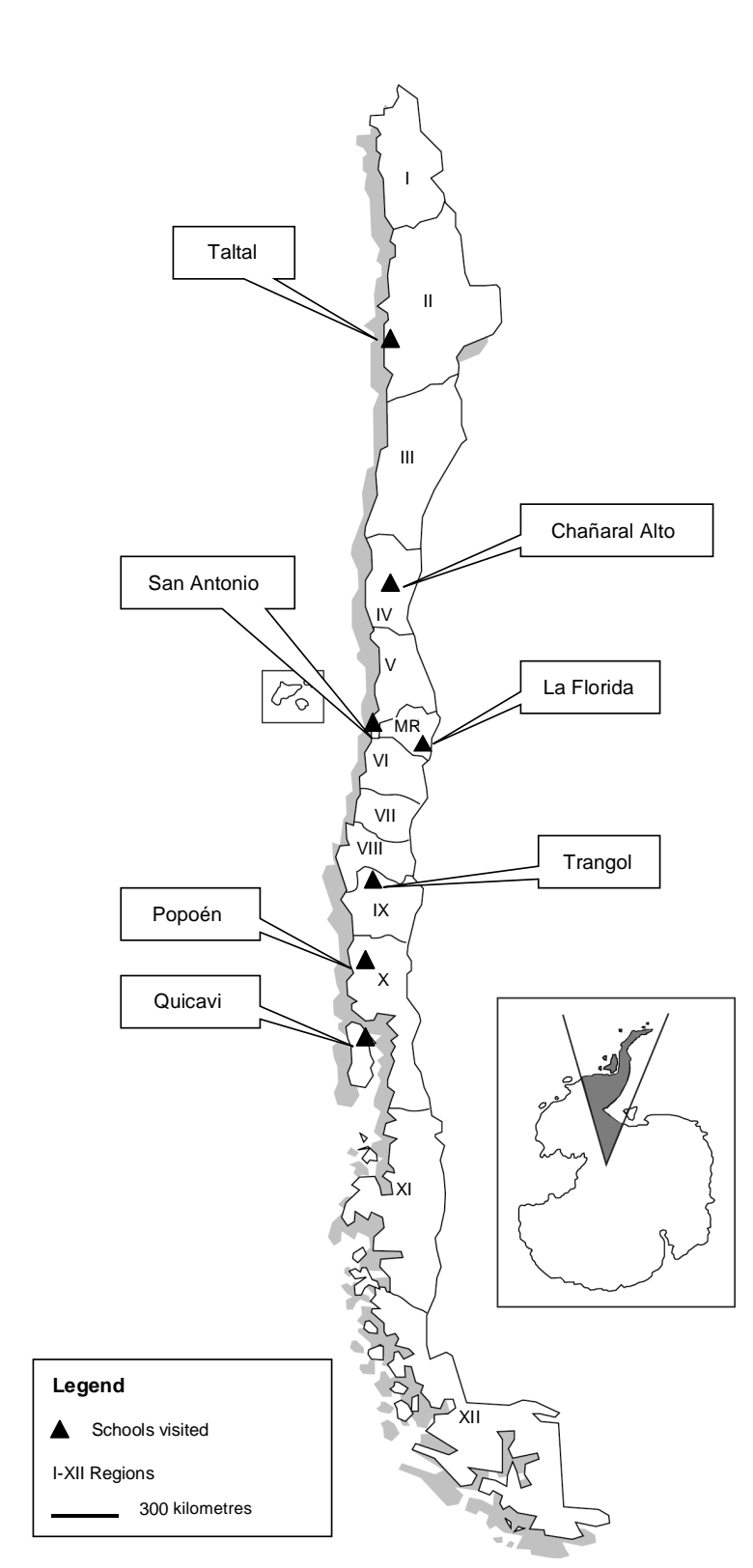

Source: Produced by author.

Source: Produced by author.

\footnotetext{
${ }^{8}$ A number of other obviously important factors that should have been considered were not taken into account because reliable and reasonably comprehensive $\mathrm{P} 900$ school data could not be made available. These included teacher qualifications, teacher turnover, teacher-pupil ratios, pupil repetition and dropout rates, school structures and facilities, the qualifications and experience of school principals and school income and expenditure.

${ }^{9}$ See Carlson (2000) for a full presentation of each of the school visits.
} 
TABLE 1

Chile: Summary of the $\mathrm{P} 0^{\mathrm{a}}$ schools visited

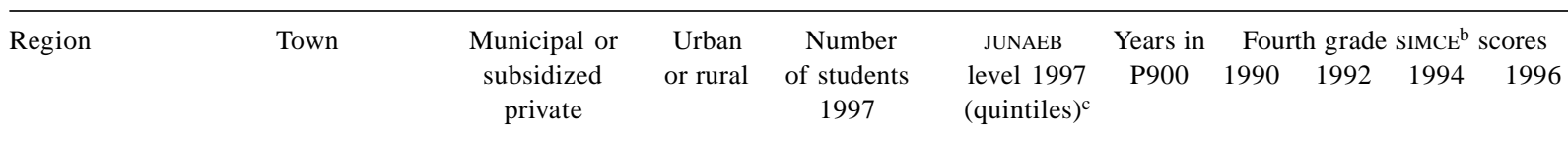

Badly performing schools

\begin{tabular}{|c|c|c|c|c|c|c|c|c|c|c|}
\hline $\mathrm{X}$ & Popoén & Subsid. & Rural & 80 & 4 & 6 & 53 & 47 & 38 & 49 \\
\hline IX & Trangol & Mun. & Rural & 72 & 5 & 8 & 30 & 32 & 41 & 39 \\
\hline XII & La Florida & Subsid. & Urban & 642 & 2 & 7 & 41 & 44 & 46 & 47 \\
\hline V & San Antonio & Mun. & Urban & 518 & 3 & 8 & 46 & 56 & 56 & 57 \\
\hline IV & Chañaral Alto & Mun. & Rural & 681 & 4 & 7 & 55 & 62 & 67 & 57 \\
\hline II & Taltal & Mun. & Urban & 1110 & 2 & 5 & 53 & 64 & 64 & 60 \\
\hline \multicolumn{11}{|c|}{$\begin{array}{l}\text { Well performing } \\
\text { schools }^{\mathrm{d}}\end{array}$} \\
\hline$X$ & Quicavi & Mun. & Rural & $\ldots$ & 3 & 6 & 55 & $\ldots$ & 68 & 70 \\
\hline V & San Antonio & Mun. & Urban & 1158 & 1 & 6 & 54 & 67 & 68 & .. \\
\hline
\end{tabular}

a $\quad$ P900 = Programme to improve the quality of schools in poor areas.

b Average of mathematics and Spanish scores.

c Quintiles 1 to 5 according to the vulnerability index used by the Junta Nacional de Auxilio Escolar y Becas (National Student Assistance and Scholarship Board) or JUNAEB.

1 = Lowest vulnerability (0-32)

2 = Low vulnerability (33-44)

3 = Medium vulnerability $(45-56)$

4 = High vulnerability $(57-66)$

$5=$ Very high vulnerability (67-100)

d In San Antonio, a contrasting, well performing school that had recently graduated from the P900 system and was just a short walk away from the under-achieving school visited was selected as a comparator. A school visit to a successful, poor, rural boarding school in Quicavi, Chiloé, is also reported as a contrast to the under-achieving rural schools that were visited in regions IX and X.

\section{IV}

\section{What schools teach us}

What makes a good school? What does it take to make a good school in a poor community? Or conversely, what keeps a school from being a good school? Our school interviews bring many realities to light and drive home the truth that parents, educators and students know: one factor alone does not make the difference. Educating young people is a complex process; many factors come into play at school. The factors are additive: good teachers, an accomplished school principal, an effective curriculum, enough money to carry out programmes, well-fed children who are motivated and prepared to learn, parental involvement, good facilities, adequate classrooms, small class sizes, schools close to home, creative teaching, a stable student-teacher population.
These factors add up to bigger challenges in schools like the ones we are considering. It takes more effort to make a good school in a poor setting; it is a continuous challenge, renewed year after year. These schools were selected because they were not doing well according to standardized examination results, but each school has distinct factors at work and each has its own lessons to teach. While the lessons here apply most directly to under-performing schools in difficult settings, they also have meaning for schools at large. We can see that these schools are not all equally "poor" or equally "vulnerable", as they come from four out of the five levels of vulnerability measured by the national school feeding programme algorithm for allocating school lunches. Socio-economic vulnerability is only one of the factors governing school performance. 
The reforms being undertaken by central authorities to improve education are medium- to long-term investments. At least five to ten years will pass before all schools see them functioning effectively. The effects of curriculum reform, teacher training and fullday education will take time to come through. In the meantime, focused efforts to improve the workings of schools are needed, within the existing parameters.

\section{What schools teach us about teacher and student performance}

The aim of the school visits was not a rigorous evaluation of classroom teaching per se. This would have required a specialized, in-depth study focusing on that topic alone and lasting for longer. Classrooms, especially fourth grade classrooms, were visited at all schools and some teaching was observed. In some classrooms students had been divided into groups, in others they had not. A lot of information emerged from the interviews with teachers, principals and students. There was a fair amount of rhetoric about child-centred learning, the result in part of current Ministry of Education policy recommendations to teachers participating in Ministry teaching improvement workshops.

The problem, of course, is to translate standards into practice. One teacher can indeed make a difference, even at a poor school. In 1992, for example, the fourth grade children at Taltal's Escuela Hogar turned in mathematics and Spanish results far higher than those of previous years (62 and 65 respectively out of 100), a result attributed to three particularly good teachers. In 1996, though, there was a drop of two points in the average score for Spanish and seven points in the score for mathematics, largely because the teachers had changed.

There is a clear difference in average age between teachers in municipal schools where they have a job for life and those in private subsidized schools where they can be dismissed. The high average age of teachers in many of the schools visited was striking. In Taltal the school principal said this was because he could not get new teachers to go to that remote place. Two of the teachers responsible for the commendable 1992 and 1994 scores had since retired and recruiting new teachers was a difficult if not impossible task. Taltal is a desert town of 12,000 , a four hour bus ride south of the nearest city, Antofagasta. The town is isolated and most goods have to be brought in by truck, so the cost of living is high. These factors conspire to keep young professionals away. "If you advertise a job opening in
Taltal nobody will apply. They all prefer the big cities," said former P900 supervisor Alfaro.

If some veteran teachers resist change, an equal number of them embrace it and use it to their advantage. Teachers responsible for first to fourth grade students in Taltal put together a project for an audio-visual room that won funds from the Ministry of Education. Because the project was devised by the teachers themselves, they also make more frequent use of this facility and have integrated it into their lesson plans. Popoén's teachers credit the school's impressive performance in science to the frequent use of educational videos, which are shown on a video cassette recorder and television obtained through a PME (Proyecto de Mejoramiento Educativo $)^{10}$ project grant.

Continuing education for experienced teachers is as important as changing the way new teachers are taught. Good videos of "ideal" classrooms and classroom teaching methods can be very effective in acquainting teachers and students with methods and practices that would improve their teaching and learning. These videos would be especially effective if they used real examples from poor schools and difficult settings.

However, large class sizes and overcrowding stood out as a major challenge to even the most innovative teacher. At the successful Portuarios school in San Antonio, the most serious problem today is the growing demand from parents wanting their children to study there. Teachers fear this could hinder the performance of the children. There are too many classes with 45 students, which hampers their ability to give the interactive classes they consider best for learning. It is also virtually impossible to bridge the differences between slow and advanced students. Very large differences in the quality and quantity of classroom learning materials, textbooks and student notebooks were readily evident, even among these troubled schools. Some schools and classrooms were especially deficient; this was the case, for example, at the Chañaral Alto school, which is not even one of the schools with the highest vulnerability level. The poor quality of students' notebooks and the individual work in them was striking. In some cases, the work was barely legible.

\footnotetext{
${ }^{10}$ The Proyecto de Mejoramiento de Educación (Educational Improvement Project) is a three-year Ministry of Education grant awarded for innovative projects to improve the quality of teaching.
} 


\section{What schools teach us about lack of parental involvement}

Lack of parental involvement was a problem in every struggling school. Although this is not a new discovery, the specific examples cited by those interviewed are certainly instructive and shed light on the depth of the problem in poor families.

The key to the seeming contradiction between innovative educational projects and poor scores in the national SIMCE tests at the Trangol school lies within the student body itself. Almost 100\% of the children are full-blooded Araucanian Indians who speak virtually no Spanish when they enter the school for the first time. Their parents enrol them more for the daily school breakfast and lunch than for the food for thought they might get during class. This is understandable considering the minimal education of the parents themselves. On average, the men have just four years of formal schooling, and half the women are "illiterate from lack of use" of reading and writing skills. These parents seldom take any interest in their children's class activities and sometimes do not even know what grade their offspring are in. When a parent-teacher meeting was held recently at the school only 10 out of 68 parents bothered to turn up. "I've never had a parent come to me and ask me how his child is doing in school. Never," said Mary Torres, who has taught at Trangol for nine years and is currently in charge of first and second grades. "We get no reinforcement at home of what they are learning. One day the kids know it and the next day they forget."

With an average of 3.5 years of schooling in Popoén, parents take little or no interest in their children's class activities. "The children here have a tremendous lack of affection and that affects their ability to learn," said their principal. The school bought a school bus to pick up weekly boarders each week and drive them back home every Friday and this has raised attendance considerably.

Most students who attend Taltal's Escuela Hogar do not receive sufficient support or reinforcement at home for what they are learning at school. Some of the older boys have to alternate between jobs and classes, working one day and going to school the next. "There is a lot of social work involved," said eighth grade teacher Rosa Ovalle Fernández, who has taught at the Escuela Hogar for 16 years.

Trifeña Tarita Chirino is a fourth grader who reads with a fluency appropriate to her nine years, despite being one of 17 brothers and sisters who work collecting and selling seaweed. Her teacher says she is enthusiastic about learning and will sometimes knock on the door after school hours to ask for a pencil or for help with a question. "I talk to Trifeña's mother and tell her to help her daughter, but it is as if I were speaking a different language," said teacher Patricia Jiménez Rojas. Trifeña's grades, which average 4.4 out of 7 , reflect the lack of parental concern. Yet in the same class, Cristián Astudillo Collao boasts grades averaging 6.2. Happy and confident, the nine-year-old announces he will be a palaeontologist when he grows up. His father works in a thermoelectric plant.

After years of fending off teacher complaints about the composition of their classes, the Escuela Hogar's principal changed the system used for deciding the makeup of each class. When parents arrive to register their children for school, they are told to select the teacher who will accompany their child from first grade to fourth. If a particularly good teacher's class fills up quickly, parents will have to settle for a different teacher. Those who carry out the registration process last will most likely get the worst teachers and condemn their children to mediocre teaching for four straight years. So in the end it is the children with parents who do not fully understand the value of education that often pay the price of the school's reluctance to take responsibility for the makeup of classes.

This unfair system enables the principal to avoid complaints and theoretically provides a motivation for bad teachers to reform. "We do this precisely so that the teacher will improve his teaching, because there shouldn't be any mediocre teachers," said Rojas. Unfortunately, he admits, there are teachers who do not care if they are chosen last, so in practice the incentive does not work. If, however, a child is lucky enough to have an excellent teacher from first to fourth grade, that child is likely to carry on being a good student in fifth grade and beyond under a normal "one teacher per subject" system.

Changes in disciplinary procedures at the big-city Unidad Divina school in the poor section of La Florida, a large district in the nation's capital, Santiago, sparked clashes with parents, who tend to be aggressive and take little responsibility for the education of their children. "The parents have a very convenient view of their children's education. They expect the school to teach everything from toilet training to academic content," said the principal. There has been no centre for parents at the school since the old one was closed. Ramón, an eighth grade teacher, considers the lack of parental support one of the school's most serious problems. "There is no 
commitment on the part of the parents, the children only get what you teach them in school."

Most parents do not participate in school activities at San Antonio's San José Calasanz School. It is not uncommon for them to send their children to work in the market, watch over cars or beg in the streets instead of going to school. Many of the children arrive without school equipment and teachers have to provide it. One teacher recalled students whose mothers never came to pick up the schoolbooks sent by the Ministry of Education. "I gave them directly to the kids, we couldn't continue to wait for their parents," he said.

Five minutes away from the struggling San José de Calasanz school, the Movilizadores Portuarios elementary school 479 in San Antonio boasts such a good reputation and attracts so many parents that its only serious problem is finding enough room for all its students. This school proves what can be achieved when administrators and parents work together and reflects the commitment of upwardly mobile, more highly educated parents from a higher socio-economic level. Parents of children at the school generally have an education that falls short of high school completion, although some have studied at university. Family life is stable, with three quarters of the students' homes composed of both parents and siblings.

The parents' centre also works actively with the school and maintains an excellent relationship with staff, who appreciate its efforts. These efforts have raised funds to improve the floors, buy books for the library, finance a new ball court, build bathrooms for the kindergarten and cover the play area with concrete. Parents have also bought a photocopier and currently pay assistants to clean the classrooms.

In return, parents expect the teachers to provide a high standard of education to their children in the classrooms. They are very interested in the school's SIMCE test results and many of them are willing to help the school with time as well as money. Some work as workshop monitors, others volunteer for special projects. Last year they worked on three special projects in the kindergarten, focusing on the family, the month of the sea and national holidays. All subjects taught in the classroom echo the chosen theme and parents pitch in with family anecdotes and work with children and school monitors to build models and displays.

\section{Lessons learned}

The school interviews tell us very clearly that while quality factors are additive, individual factors can make a difference, either for better or for worse. These factors are the critical ones to identify and understand because they are the ones that need to be acted on in the short term. What the school stories tell us, reinforcing international experience, is that the single most important factor at the school level is having a top-notch principal with the authority to act. Our school experiences make it crystal clear that a stable, qualified, motivated teaching staff is the lifeblood of a good school. They demonstrate that a skilled and dedicated teacher makes a measurable difference in student outcomes. By contrast, high teacher turnover and low teacher qualifications and interest immediately result in lower student performance.

The central problem is to attract and retain qualified teachers and talented principals in poor, remote areas of Chile and difficult inner city schools. Financial incentives are not enough. They do not address the desire of most people to live near their families and friends. Young teachers just starting out are motivated and not yet tied down to family responsibilities. They are in a position to move to communities in need, although they cannot be expected to stay there for the long term, perhaps not for more than five years. In return, they could be granted scholarships for advanced study or other incentives which would compensate them for their contribution to poor communities and poor students and would also be a further human capital investment in Chile's future.

But how can these lessons be put into practice? Educational authorities could institute school management reviews, like the ones that have been carried out here, to identify significant problems and practices that can be put right. While quantum leaps in quality are not realistic in most settings, finding and correcting one or more acute problems can make an important difference to children's learning, as the school audits demonstrate. In Chañaral Alto it is getting teachers to stay, 
in Taltal it is negotiating with the mayor, changing the school principal and sorting out school financing, and so on. Let us review the lessons from these schools in difficult circumstances, lessons that reflect their struggle to raise student achievements.

\section{Achieving educational quality: a renewed challenge every year}

Schooling in poor neighbourhoods provides the biggest challenge to school officials and students. Using trends in SIMCE scores to measure success can be misleading because the assumption is that they should continue to rise as special attention and special inputs are directed at the school. With good teaching and good school direction, test performance should go up. It will not necessarily do so, however, because each year a new cohort of kindergarten or first grade students starts afresh and presents school authorities with the same challenges all over again. This is important when it is considered that as much as $60 \%$ of achievement is attributable to the social context in which children grow up, out-of-school factors like the home environment and parental support or lack of it. "The household's educational climate (years of education of the adults in the household) is the most important factor and accounts for between $40 \%$ and $50 \%$ of the socio-economic and family factors." 11

If the characteristics of the student population changed markedly from year to year, this would affect potential school achievement results. In most cases, the student population probably does not change that much and so teachers face similarly large challenges every year. In a sense, though, SIMCE performance is misleading. The biennial tests taken by fourth grade students are an independent event each time and it is a fresh set of students that is being tested. Therefore, trends in SIMCE scores are not a very accurate measure of whether a school continues to need compensatory intervention programmes such as P900 or is ready to graduate from them. (Subsequent to these school reports, P900 introduced additional qualitative factors into the criteria for deciding whether a school is ready to graduate). A school may have become successful after participating in the programme for a few years, and the SIMCE results may reflect this. But is that the right time to leave or is it better for the school to stay in and help a new cohort of first grade students receive a higher quality education?

${ }^{11}$ See World Bank (1995), Carlson, ed. (1999), ECLAC (1998) and Cohen, ed. (1998).
Why should schools be expected to perform as well when their resources are being reduced?

\section{Achieving educational quality: making improvements sustainable}

To graduate from P900, schools need to undergo a fundamental change in the way they do business. School administrators and teachers, and not just students, need to learn from the programme. P900 must find ways to provide sustainable inputs so that the school can manage on its own better than it had been doing before it participated in the programme. It is the school that should be tested, not just its students, to monitor what it has learned. The fact is that P900 is only one complementary programme with limited resources. Probably, and the school stories bear this out, it is school-wide factors that matter when it comes to sustained improvement, and not special programme factors. P900 has provided excellent materials to stimulate teachers and students, and its school management and outreach strategies are valuable. They may not, however, be sustainable.

Overall test scores do not tell the whole story either. In each and every school visited, even the poorest and most backward, some children stood out; they hungered for knowledge and were getting as much as they could from what the school offered. At the San José de Calasanz School in San Antonio, it was possible to identify a large of number of students with learning problems who needed remedial help. The school was doing its best to attend to these children. Side by side with them, though, were others who were being challenged in the classroom and by special programmes and after-school activities such as the school newspaper. The school had many sponsors from the community who gave their money, their time and their skills to make the school better.

\section{What makes a good school: it's the school principal}

The single factor that seems to matter most is the school principal. The school principal can turn a school around. The changes introduced by Dora Muñoz at Unidad Divina school in Santiago's La Florida district have taken three years to make a difference, but they are beginning to pay off, as the SIMCE 1997 eighth grade test results showed. She has wrought a transformation in her poor, difficult, overcrowded school, changing everything from the teachers to the level of hygiene. Another example is Elsa Carrasco, principal of San 
Antonio's San José de Calasanz Elementary School, whose dedicated, creative, entrepreneurial drive has overcome adversity, making her school a centre of her community and a place where children of all abilities are challenged. Again, after two decades Ivan Rodríguez Mercado, the principal at Trangol, continues to make his tiny, remote school a warm and welcoming learning experience for its ultra-poor children.

But leadership was clearly missing in Taltal's Escuela Hogar, and this was due as much to the authoritarian mayor as to the tired school principal. Chañaral Alto's Alejandro Chelén Rojas Elementary School awaits a new school principal and in the meantime Claudina Rodríguez, filling in as temporary principal, has her heart in the right place and gives of her best, but is clearly handicapped by the lack of mandate. What the Chañaral Alto school needs to shift gears is a tough, dynamic leader who can turn the teacher situation around.

An important change that Quicavi's innovative principal introduced was the idea that all teachers should share in school administration. "When you share the responsibilities and decision-making, you get a more committed staff," he says. "It's democracy." Out went the heavy rote learning that had previously typified the school's teaching. In came more discussion, explanation and discovery. The PME school programme paid for teachers to get special training in using the school's new equipment, and in such subjects as speech skills.

The school's low results in national testing began to show a steady improvement. Class repetition fell from as high as $25 \%$ to $1 \%$. For the first time Aquelarre School in Quicavi on the island of Chiloé had no dropouts. Pérez credits his staff of seven teachers with the school's turnaround. "Once we got beyond some initial resistance to giving up old [teaching] ways, everyone adopted the project like a team, and we found we could have fun while doing a better job," he says. Teachers take it in turns to live at the school for a week at a time to supervise boarders. It makes for long days, but both teachers and students mention the sense of community when listing the school's strong points.

Pedro Martínez, Provincial Department Head for the Ministry of Education in the X Region, believes that the key ingredient in making a good school is the principal. "The success of a school depends upon the leadership of its principal. If you have a good principal, you will attract good teachers who will put together good projects to win good grants," concluded Martínez.

Incentives are needed to attract more dynamic leaders to work as principals, especially in these tough schools. It is really no different from turning around a failing company. Why not actively search for school managers with entrepreneurial, managerial and people skills and give them the authority they need to make a good school? It is clear that the quality of the students entering schools is not going to change significantly until the problems of inequality and poverty are addressed, and these are long-term problems. In the meantime, the school system can confront the special challenge of difficult schools by allocating its best leaders to them.

\section{Jornada completa: full-day schooling}

It should be remembered that the school visits were being carried out while many of the educational reforms referred to earlier were at the implementation stage, and while it is anticipated that these reforms will result in a higher quality of education, this will take time. When this process is going on it can be disruptive as well as helpful. The move from half-day to full-day education means in practice that many schools have to find two or even three times the physical space to implement this reform. It is not just a question of financing. In many poorer schools like the ones in this study, there is simply not enough space left in the current physical premises. These schools are already overcrowded after many years of growth within the same infrastructure. The logistics of giving over the available space to one shift means that, as a minimum, the number of classrooms has to be doubled. In most of the schools visited this was not feasible. The municipalities are having to search for alternative sites and the logistics of implementing the change has wide-ranging implications for other school inputs such as teachers, recurrent costs and the building of new premises which old schools are not able to accommodate. There is now a special Ministry programme to help schools solve these problems.

\section{Accountability}

The quality of education in schools is suffering from an almost total dependence on outside decision-making and outside financing by three principal actors: the Ministry of Education, the provincial department and the municipality or private administrator. The bulk of financing continues to come from the central authorities in Santiago in the form of a subvention or payment per child. This is calculated on the basis of monthly attendance records and handed over to the municipality to administer. The municipalities manage the schools 
and are expected to provide additional financing for equipment and school operations. The Ministry of Education in Santiago is responsible for curricular and pedagogical aspects. The provincial departments supervise the implementation of Ministry programmes by schools.

There needs to be more coordination and accountability among these three actors. At the moment, schools are being "graded" only on their SIMCE performance. In large part school SIMCE performance is determined by the quality of school staff, i.e. teachers and administrators in the schools. However, decisions about school staff are not made by schools but by the local municipal authorities. Where is the municipality's grade? Somehow the linkage between the school, the municipality, the Ministry and the provincial authorities needs to be improved, and some checks and balances instituted.

\section{High student-teacher ratios}

Under Chilean law, schools can assign as many as 45 students to a classroom and receive a subvention for each of them; there is no subvention for students above 45 . Schools thus have a very powerful economic incentive to have classes as close to 45 as possible. How can one teacher manage a class of 45 students and provide them with a high-quality education? Certainly it is not optimum. By way of comparison, the average class size in private schools throughout the country is 24 students per teacher, as against 38 for all private subvention-funded schools and 35 for all municipal schools. ${ }^{12}$ This problem was particularly noticeable in poor private subvention-funded schools, schools that are privately owned but which receive the per capita student subvention. A case in point is the Unidad Divina School. Because of its limited resources, it depends heavily on the subvention to pay for its major operations, and especially to fund reasonable salaries for its teachers. Consequently, the teachers themselves, together with the administration, went on a campaign to recruit more students. The Popoén school generally operates at a loss, according to its owner, who had to return to teaching at the school to save on the salary of another teacher.

How does this stack up with international experience and knowledge? There has been much debate about class size because of the high cost of smaller classes. There are a range of views on the subject and

${ }^{12}$ See Chilean Ministry of Education (1998). the evidence is different for different levels of schooling. Hitherto, small class sizes have tended to be regarded as inappropriate, at least for "developing countries", because they are not cost-effective. ${ }^{13}$ This general guideline does not discriminate sufficiently between different developing countries, however, and while it may be a reasonable prescription for very low-income countries, it is not necessarily the right one for others, like Chile. Furthermore, why is it necessary to apply class size rules across the board?

There is much new evidence regarding the cost and effects of class size reduction (CSR) and much remains to be learned. ${ }^{14}$ To judge by short-term effects at least, CSR prompts significant academic improvement. In class size experiments in the United States, the effects on minority student were double those on white students. Most improvement was shown during kindergarten and first grade. The long-term effects are harder to gauge because other factors make it difficult to isolate the results. Care also has to be exercised with the definition of small and large classes. In the United States, where much of this research is carried out, small is very small in Chilean terms (less than 20 students per class as compared with more than 20 , for example). As would be expected, the results of current research show that the opportunity costs of giving students individual attention are greater in large classes, and with a smaller number of students the teacher is able to spend less time on discipline and more time on instruction. In a smaller class, the teacher is able to give more individual instruction, usually to those students who do not have parental support at home. Low-income and minority students benefit the most from class size reduction.

In some East Asian countries such as Japan and Korea, CSR does not produce the same results as in the United States. The Third International Mathematics and Science Study (TIMSS) shows that while class sizes are large in these countries, students' academic performance is also high. However, teachers in Japan teach their students by lecturing and the lectures are the same regardless of the number of students in the class. In Chile, education reform is aiming for a switch from the "frontal" approach to "interactive" teaching, requiring more individual attention.

Parental involvement is crucial for successful learning, especially when class sizes are large. Even with a class of less than 20 students, a teacher can spend only

\footnotetext{
13 See Lockheed and Verspoor (1991).

14 See Grissmer (1999).
} 
a limited amount of time on each student. Parents can easily spend more time with their children. However, students from poor families do not receive parental support and schools are being called upon to make good this deficiency in the transition from home to school, especially in the early years of education. There is evidence of significant short-term achievement gains in the first four years of school with CSR.

\section{Overcrowded classrooms}

How can quality learning take place when large numbers of students are packed into small classrooms? Crowding was found in a number of the schools visited, but it was particularly evident as a serious problem at Unidad Divina School located in the commune of La Florida in Santiago. Forty or more children were packed into the small classrooms and seated so close together that they were literally "shoulder to shoulder". This problem was exacerbated by the move to full-day schooling, as some classes were now operating throughout the day and displacing other classes that would otherwise have used the same rooms in the afternoon shift. In Taltal's Escuela Hogar, 40 plus children were stuffed into classrooms designed for no more than 35 children. Overcrowding was observed in all but the smallest schools.

\section{Teacher turnover, teacher qualifications, teacher involvement}

Chañaral Alto's Alejandro Chelén Rojas Elementary School shows us how much teachers do matter. Its children are starved of teacher involvement. Children must question their own worth when they experience their teachers' lack of commitment, watch them rush off at the end of the day for the long drive back to civilization in the nearest big town, call in sick as often as possible or quit as soon as they can. Only 13 of the 26 teachers currently live in Chañaral Alto, the rest commute. The SIMCE scores for the fourth grade plunged in 1996 because that cohort went through 12 different teachers in a four year period. Those in eighth grade, meanwhile, had had just one excellent teacher from first grade to eighth and their 15 point increase in SIMCE scores reflected that. Because of the difficulty of finding teachers, 11 out of the 26 lack degrees. None of the seven new teachers has one. The school has had three principals within the space of a year and the position is vacant again. This is clearly a disaster that needs to be sorted out. If the school cannot keep teachers then why keep the school in the town? Why not transfer the school to the nearest large community and bus the children in? The cost-benefit implications and impact of such a change warrant consideration.

The Chañaral Alto example may be representative of an underlying problem worth investigating further: the problem of getting good teachers for rural schools that are too remote for convenient travel but not so distant that teachers would choose to live in the community.

At Unidad Divina School in the Santiago district of La Florida, the principal thought that her team of teachers had learned to work well together and was happy that teacher turnover had decreased. Being private, the school could change its teachers, unlike municipal schools where the teachers' union and the law strictly regulate teacher contracts.

Most of the 16 teachers at Unidad Divina came from professional institutes. Almost all the teachers spent the entire day at the school, since their contracts stipulated a working week of 44 hours. Teachers earned a modest basic salary, but the school had begun awarding bonuses as an incentive for efficient and effective teachers. While the teachers appreciated the principal's efforts and the ease with which they could get their new projects approved by her, low wages continued to be a source of frustration, particularly when higher qualifications did not translate into higher salaries. "It doesn't pay to get extra training," said Ramón, who said the school only provided a small part of the financing for his graduate degree in counselling and did not raise his pay after these additional studies.

\section{School financing: a case of reverse targeting}

The Taltal School provided a major insight into how educational reform can work in practice or, in this case, not work in practice. The Taltal School was visited because it was an instance of a very large school whose performance had improved, stagnated and then started to slide back, in spite of P900 and other project and programme interventions. The Ministry had conjectured that it was in large schools that it was likely to prove especially difficult to achieve sustained improvements. At the same time, the Taltal School is not a particularly poor school as measured by the JUNAEB vulnerability index used as a basis for allocating school lunches. On a scale of 1 to 5, the Escuela Hogar scored 2, placing it in the low vulnerability category. The physical infrastructure and the children seen during the visit appeared to be in better condition than at any of the other six under-performing schools visited. 
It transpired that the local mayor, who had the authority to decide how the municipality's school funding would be spent, elected to take funds from the poorest and biggest school in his town, the Escuela Hogar, in order to pay for the operations of the secondary schools and night schools, which were operating inefficiently owing to their lower enrolment rates and unreliable attendance. The Escuela Hogar, with its 1,110 primary students and compulsory attendance, was generating a reliable flow of income, but part of this was being transferred away to finance the rest of the system. Meanwhile, the school was lacking in basic infrastructure; there were not even enough chairs in the canteen.

This case perfectly illustrates the importance of studying micro as well as macro performance; the need to observe the "how" at first hand, and not just rely on the facts that reach the top. Without this local information, the normal assumption would have been that child-based subventions to schools would be spent as they were allocated in the schools for which they were intended. It may also help to explain why some senior Ministry of Education officials were of the opinion that the serious "hard cases" were the very large schools. There may be other examples of municipalities reallocating funds from larger primary schools to cover the costs of smaller schools, more expensive secondary schools and schools where attendance is not mandatory and is therefore irregular, resulting in lower subventions. What with the current recession and economic crisis, municipalities are seeing their budgets cut even further and this practice may well become more common. It is truly a case of reverse targeting.

\section{Special programmes competing with the basics}

Many schools are receiving special programme inputs designed to improve the quality and relevance of education. In addition to P900, most of the schools visited had won PME (Educational Improvement Project) funding. In 1995, 736 project grants were awarded through primary school competitions in a range of learning areas: language, subject integration, social integration, mathematics, natural sciences, social sciences, art and physical education. The equivalent of over US\$ 4 million was awarded to primary schools, giving an average of US $\$ 6,000$ per school in current dollars, for projects lasting two to three years. The overwhelming majority of these grants, over $60 \%$, were awarded in the language area. A typical example is the television project won by the Quicavi School in Chiloé, which was so instrumental in bringing learning alive for those students.

While these projects and programmes provide enriching opportunities for students, they also compete for the time and attention of teachers and administrators. More than one school remarked on this conflict. In Chañaral Alto, for example, the school with the most serious difficulties in attracting and retaining qualified teachers and staff, school officials, while very proud of their PME project, also expressed concern about the less than optimal implementation of P900 due to the time demands of the PME and other projects. Winning the PME project involved setting aside time to write up the proposal and, when the award was made, spending time implementing and supervising it. In addition, schools receive a number of different special programme inputs for which they must compete. This is not to say that these are not useful projects and programme inputs, but there is a resource cost involved.

The innovative Enlaces project to give students hands-on experience with computers is another example. The project requires a special secure, dedicated room. Teachers must be trained first to use the computers and then to train and supervise their students. At the Unidad Divina School in La Florida, the library had been sacrificed to the Enlaces project since there were no spare rooms available. The impression that one is left with is of a two-tiered quality effort: innovative projects on the one hand, but failure to get to grips with classroom basics on the other. In Taltal, the Escuela Hogar was long on frills and short on the basics, with computers still standing boxed up and donated laboratory equipment proudly displayed in the multimedia room while children were following what for the most part was the same old routine in the classrooms.

\section{1. "Home" work or supervised exercises at school?}

Homework may be set, but it is very difficult for many poor students to find a quiet place to work at home. Many households have no private areas. Instead, children probably have to share the dining room table with other family members while they are watching television or talking or entertaining friends. Parents with little education are less prepared to support their children and less aware of how to go about it, homework being a case in point. Ramón, an eighth grade teacher at the Unidad Divina school in La Florida, Santiago, considers this a serious problem: "At home their school bag gets thrown in a corner, they don't open it, and in most cases they have nowhere to study. If they do try to study, it is at a 
table with a radio on, a television blaring and a bunch of kids yelling." This type of comment was echoed in most schools with achievement problems, while in the "successful" Movilizadores Portuarios school in San Antonio parents hold the teachers to high standards and are very interested in the school's SIMCE results. They give their time not just at home but in the school, working as workshop monitors and volunteering for special projects. Rather than complaining about these hard truths, a more constructive solution could be to provide a "home" work setting at the school and carry out supervised exercises in homework rooms after hours.

\section{What should be done about textbooks?}

Textbooks give concrete expression to the curriculum and enable students to study independently. Each year the Chilean government invites tenders for the provision of school textbooks for children in State-supported education, who account for over $93 \%$ of total enrolment in the country. The unsatisfactory supply of textbooks is still a serious handicap to quality education and further efforts to improve the quality of textbooks are needed.

Teachers frequently complained that they did not have enough textbooks, and that those they did have were of poor quality. When the Ministry of Education sends out questionnaires on which textbooks teachers wish to receive, Ovalle Fernández, a teacher at the Escuela Hogar in Taltal, makes her choices carefully, but to no avail. "We always choose the best and we always get whatever is available," she complained. A teacher at the San Antonio Movilizadores Portuarios school said "I was furious when I discovered that the language book from the publisher Arrayán supplied by the Ministry is sold in bookstores with a workbook that we never get. So that means we are already at a disadvantage before we even begin." Some teachers review the new school texts every year then buy the most useful ones with their own money and photocopy them for their students, charging only for the photocopying.
Although textbook evaluation was not the focus of this study, the issue was looked into. Whereas in 1990 many children had to share textbooks, in the ten years since then the Ministry of Education has tripled the number of textbooks provided to schools and has stated that in the school year beginning March 2000 all students in basic education will have their own textbooks. Efforts are also under way to improve textbook quality in connection with the curriculum reform.

Given the centrality of textbooks to educational outcomes, why are they not better and what needs to be done to change the situation? A big research study by the Centro de Estudios Públicos (Centre for Public Studies or CEP) provided an in-depth assessment of the quality of textbooks being used in Chilean schools receiving government subventions. ${ }^{15}$ The CEP study put together two commissions: one to evaluate mathematics texts and another to evaluate Spanish language textbooks. The expert panel included people from rich, middle class and poor backgrounds, university teachers, users of mathematics and Spanish texts and school principals. They agreed that Chilean textbooks did not measure up to the foreign textbooks from countries like Spain and England that were used for the purposes of comparison, and came up with conclusions and proposals regarding language and mathematics texts.

Textbook reform could be a relatively quick way to make an impact on education quality at the student level. Good textbooks can produce immediate improvements in classroom and personal learning. There is not much in the way of choice among the texts available on the market. However, the Ministry is evaluating the bidding process and the texts being used. This is very welcome, but the critical issue remains that Chilean texts are below international standards and there cannot be a real change in the near future unless the basic issue of standards is addressed. As basic education is undergoing curricular reform, an accompanying textbook reform is an urgent priority.

\footnotetext{
15 See Eyzaguirre and Fontaine, eds. (1997).
} 


\section{VI}

\section{Conclusion}

The many lessons learned from the in-depth school visits will be directly relevant for a significant proportion of the country's subsidized primary schools and will be very important for improving the quality and equity of primary education. The school interviews show that while quality factors are additive, some individual factors make a great difference. These factors are the critical ones to identify and understand because they are the ones that need to be acted on in the short term. The school stories show that the most important factor at the school level is having a top-notch principal with the authority to act. They also show that a stable, qualified and motivated teaching staff is the lifeblood of a good school and makes a measurable difference to student outcomes, whereas high teacher turnover and low teacher qualifications and interest immediately result in lower performance. The central problem that faces us is to attract and retain qualified teachers and talented principals in poor or remote areas of Chile and difficult inner city schools. 


\section{Bibliography}

Angell, A. (1996): Improving the quality and equity of education in Chile: The programme 900 escuelas and the MECE-básica, A. Silva (ed.): Implementing Policy Innovations in Latin America: Politics, Economics and Techniques, Washington, D.C., Inter-American Development Bank (IDB).

Carlson, B. (2000): Achieving Educational Quality: What Schools Teach Us, Desarrollo productivo series, No. 64, Santiago, Chile, Economic Commission for Latin America and the Caribbean (ECLAC), January.

Carlson, B. (ed.) (1999): Social Dimensions of Economic Development and Productivity: Inequality and Social Performance, Desarrollo productivo series, No. 56, Santiago, Chile, EClaC, August.

Carnoy, M. and P. McEwan (1997): Public Investment in Private Schools: A Reconstruction of Educational Improvements in Chile, Stanford, California, Stanford University.

Chile, Ministry of Education (1996): Compendio de información estadística 1996, Santiago, Chile, Department of Statistics.

(1998): Compendio de información estadística 1998, Santiago, Chile, Department of Statistics.

Cohen, E. (ed.) (1998): Educación, eficiencia y equidad: una difícil convivencia, Educación, eficiencia y equidad, Santiago, Chile, ECLAC/Organization of American States (OAS)/Ediciones SUR.

Cox, C. (1997): La reforma de la educación chilena: contexto, contenidos, implementación, Documentos PREAL, No. 8, Santiago, Chile, Partnership for Educational Revitalization in the Americas.

EClAC (1998): Social Panorama of Latin America, 1997, Santiago, Chile.

Espínola, V. (1996): Revisión de quince años de política educativa en Chile: ajustes en función de la equidad, Santiago, Chile, EClAC.

Eyzaguirre, B. and L. Fontaine (1999): ¿Qué nos dice el SIMCE de $8^{\circ}$ Básico? Análisis y perspectivas, Documentos de trabajo series, No. 294, Santiago, Chile, Centre for Public Studies.

Eyzaguirre, B. and L. Fontaine (eds.) (1997): El futuro en riesgo: nuestros textos escolares, 1997, Santiago, Chile, Centre for Public Studies.

Gajardo, M. (2000): Reformas educativas en América Latina. Balance de una década, Partnership for Educational Revitalization in the Americas paper, No. 15, Santiago, Chile, Partnership for Educational Revitalization in the Americas, January.

García-Huidobro, J. (1999): La reforma educacional chilena, Santiago, Chile, Editorial Popular.
García-Huidobro J. and C. Jara (1994): El programa de las 900 escuelas, M. Gajardo (ed.), Cooperación internacional y desarrollo de la educación, Santiago, Chile, Ministry of Planning and Cooperation, International Cooperation Agency/SIDA/Centre for Educational Research and Development.

Grissmer, D. (1999): Seminar on Class Size Effects: Assessing the Evidence, its Policy Implications, and Future Research Agenda, Washington, D.C., RAND Corporation, September.

Lockheed, M. and A. Vespoor (1991): Improving Primary Education in Developing Countries, Washington, D.C., World Bank.

Martínez, R. (1996): La prueba SIMCE y la medición de la calidad de la educación, Educación, eficiencia y equidad, Santiago, Chile, ECLAC/OAS/Ediciones SUR.

Mizala, A. and P. Romaguera (1998): Desempeño escolar y elección de colegios: la experiencia chilena, Working documents, Economía series, No. 36, Santiago, Chile, University of Chile, Department of Industrial Engineering, Centre for Applied Economics.

National Student Assistance and Scholarship Board (1998): JUNAEB, Red nacional de apoyo al estudiante, programas 98.99, Santiago, Chile.

Olivares, J. (1996): Sistema de medición de la calidad de la educación en Chile: SIMCE, algunos problemas de medición, Revista iberoamericana de educación, No. 10, Madrid, Organization of Ibero-American States for Education, Science and Culture.

Partnership for Educational Revitalization in the Americas (1998): The future at Stake, Washington D.C., InterAmerican Dialogue, April, mimeo.

Rojas, C. and J.M. Esquivel (1998): Los sistemas de medición del logro académico en Latinoamérica, LCSHD paper series, No. 25, Washington, D.C., World Bank, Latin American and Caribbean Regional Office, October.

Schiefelbein, E. and P. Schiefelbein (1998): Repetition and quality of education in Chile, L. Randall and J. Anderson (eds.), Schooling for Success, New York, Sharpe.

Undurraga, C. (1998): Reforma educacional en Chile: perspectiva de cinco ministros, Washington, D.C., IDB, mimeo.

World Bank (1995): Priorities and strategies for education, Washington, D.C.

(1999): Educational Change in Latin America and the Caribbean, World Bank strategy paper, Washington, D.C., Latin America and the Caribbean Social and Human Development. 